\title{
EMPLOYMENT STATUS FOR PEOPLE WITH DISABILITIES IN GREECE
}

\author{
GEORGE N. MAGOULIOS ${ }^{\mathrm{a}, *}$ \\ ANNA TRICHOPOULOU ${ }^{b}$ \\ ${ }^{a}$ Technological Education Institute (TEI) of Serres, Greece \\ ${ }^{b}$ Health Regional Authority of Macedonia and Thrace, Greece
}

\begin{abstract}
This article reviews the status of individuals with disabilities in Greece, based on data from a primary research carried out within the framework of Community Initiative Programme (CIP) Equal. In particular, the article examines the features of people with disabilities, the relation of educational studies to occupation, and the factors which influence the decision to work. It investigates the interest of disabled people in working, their current and past employment status, the field and the duration of employment as well as the importance of several factors contributing to job-seeking. In addition the article examines the means exploited in the process of finding a job, attitudes while working, as well as comparing the performance of disabled people at work to that of other employees. The findings of the research reveal to a full extent the problem of exclusion of disabled people from employment and point out the need for initiatives on behalf of the state in order to provide some solutions to tackle the problem.
\end{abstract}

JEL Classification: J71

Keywords: Disabled People, Employment, Greece

*Corresponding Author: George N. Magoulios, Agia Triada, P.O. Box. 6510, 57019 Thessaloniki, Greece. e-mail: magulios@teiser.gr 


\section{Points of interest}

The article reviews the employment status of individuals with disabilities in Greece, as indicated through the outcome data of the primary survey on disabled people experiencing any form of discrimination.

This study showed that the need for survival seems to be the most important factor influencing the decisions of disabled people on employment.

Through the evaluation of attitudes at work it emerges that the behaviors of colleagues, employers, customers and managers are quite satisfactory for most employed people with disabilities.

Personal skills, particularly interpersonal social skills, appear to be crucial for successful performance of the disabled at work. The research found that the means which is most frequently used in the process of job-seeking is personal or family acquaintance with the employer.

\section{Introduction}

This study investigates the employment status of people with disabilities in Greece as indicated through the outcome data of the primary survey on disabled people experiencing any form of discrimination, a survey which was carried out within the framework of Community Initiative Programme (CIP) EQUAL 1 and the project "Proklisi". In the past, any planning and implementation of Greek policies regarding inclusion in the labour market was implemented mainly by the Greek Organization for the Employment of the Workforce (OAED) and included mostly policies on premiums and benefits. It was not until the 90's that this situation changed towards a direction of mainly active policies and, hence, a wider range of policies and measures were implemented. EU funds contributed significantly to planning and implementing dynamic policies on vocational training, consulting, vocational guidance and occupational experience etc. The supporting services provided for people with disabilities are the following: inclusion in vocational training programs, actions facilitating accessibility and rehabilitation in the labour market, subsidizing of employment providing the employers with specific motives so that the employment of disabled people will become easier, incentives for business entrepreneurship with subsidies to young professionals who set up small businesses or form partnerships. Respective quotas are promoted to all companies (Law N.648/86 and Law N.2643/1998), either public or private, which employ more than 50 people and oblige them to employ disabled people for at least $5 \%$ of the total posts in the company. However, despite all institutional regulations, disabled people have been underrepresented in the labour market.

The study question which the present article is attempting to answer is: what is the employment status of people with disabilities in Greece? In particular, the article examines the features of people with disabilities, the relation of educational studies 
to occupation, and the factors which influence the decision to work. It investigates the interest of disabled people in working, their current and past employment status, the field and the duration of employment as well as the importance of several factors contributing to job-seeking. In addition the article examines the means exploited in the process of finding a job, attitudes while working, as well as comparing the performance of disabled people at work to that of other employees.

\section{International and European reports on the employment status of the disabled}

According to ILO evaluations, 650 million people - one out of every ten people in the world - are disabled and 470 million $(72.30 \%)$ of them are of working age. It is noted that disabled people often face disproportionate levels of poverty and unemployment, adding that an estimated $80 \%$ of all people with disabilities live in developing countries, of whom 426 million live below the poverty line. Access to employment is the most cost-effective way to reduce the poverty of people with disabilities (ILO ILO 2007).

According to results of surveys contacted in the $25 \mathrm{EU}$ countries in 2002, some 44.6 million people aged between 16 and 64 consider themselves to have a Long Standing Health Problem or Disability (LSHPD), representing 15.7\% of the overall EU working age population. The percentage of the working-age population with LSHPD varies widely among countries, and in Greece it is found to be $10.3 \%$ (Eurostat, 2003, pp. 1-3). A further issue arising from the results is a prevalent linking between disability and ageing. The number of people with disability in the EU has increased and is going to increase more due to long-term ageing of the population and the improvement of medical care. Figures also indicate a gap between the employment rate of disabled and non-disabled people: in $2003,40 \%$ of people with disabilities were employed compared to $64.2 \%$ for non-disabled, while $52 \%$ were inactive against $28 \%$ for the non-disabled (European Commission, 2005). The more severe the degree of disability, the lower the participation in the labour force: $78 \%$ of the severely disabled aged $16-64$ are outside of the labour force as compared to $27 \%$ for those without LSHPD. And even among those in the labour force, the unemployment rate is nearly twice as high among the severely disabled as compared to the nondisabled (Eurostat, 2003, pp. 1-3).

In Greece, according to the findings of the Labour Force Survey of individuals with LSHPD, $84 \%$ are economically inactive, compared to $58 \%$ of the general population of the country. About $50 \%$ of disabled employees face problems in their working environment. $40 \%$ of the disabled claim to be victims of social exclusion, owing to insufficient income, unemployment and the inadequacy of social services (Report with main findings of the 2002 Survey "Individuals with disabilities" in Greece, NSSG). 
From the total expenditure on labour market policies in the EU-15, in 2003, a share of $7.96 \%(10.728,4$ millions euros, $0.11 \%$ of GDP) was allocated to integration of disabled people. In Greece, only 33.1 million euros $(0.02 \%$ of GDP) was allocated to integration programmes for people with disabilities (Eurostat, 2003, p. 12, 14). Little attention was paid to disability by the European Economic Community and the founding Treaties of the European Union and it was not until 1993 that the social inclusion of disabled people in Europe became a matter of concern, in response to the 1993 United Nations 'Standard Rules on the Equalization of Opportunities for Persons with Disabilities' (United Nations, 1993). After the recognition of disabled people as consumers and workers in the 1996 European Day of Disabled Persons and under pressure from disability organizations, the disabled were finally dealt with as European citizens in the Amsterdam Treaty (Priestley, 2002, pp. 846-848).

Article 13 of the European Community Treaty, which was introduced following the Amsterdam Treaty, provides support and power to the Community to legislate to combat discrimination based on sex, racial or national origin, religion or beliefs, disability, age or sexual orientation. Directive 2000/78/EC lays down common rules and puts emphasis on the need for measures against all forms of discrimination and particularly in matters of occupation and employment (Official Journal L 303, 02.12.2000).

After the report of the Commission to the Council, the European Parliament and the Economic and Social Committee and the Committee of the Regions - Towards a free-barrier Europe for People With Disabilities \{COM (2000) 284\}- aiming at raising public awareness and consideration as well as the promotion of new strategies, the year 2003 was "European Year of People with Disabilities". The initiative "Employment" provided support to people facing difficulties in finding a job or maintaining one.

The European Commission adopted an Action Plan (2004-2010) on equal opportunities for people with disabilities, which is intended to define a sustainable and functional approach to issues concerning disability in the enlarged Europe. The plan mentioned pursues three main objectives: successful implementation of the Directive on equality with regard to occupation and employment, further inclusion of Disability in the Community policies and promotion of equal access opportunities for all (European Commission 2003, 2005).

It has been pointed out that governments of industrial and developing countries have the ability to promote employment for people with disabilities via exploiting technology and implementing relevant policies, programmes and strategies. They can either act as employers appointing disabled people in the public sector or use their tremendous purchasing power as consumers of goods and services to influence members of the private sector to employ people with disabilities (Cohen D.F.B., Zeitzer I.R., 2004, p. 45). 
People with disabilities are at great risk of remaining unemployed or inactive while a high proportion of those employed are in low-paid jobs. Participation in employment is crucial not only for earning a decent living but also for their active involvement in the community. In Member States of the EU, people with disabilities are facing several restrictions when trying to find a job or maintain the one they have. According to the European Community Household Panel, an individual in the productive age-range of 16 to 64 years stands a $66 \%$ chance of finding job or setting up a business. For a person with mild disability, this chance comes down to $47 \%$, whereas for people with severe disability, it drops to $25 \%$. Countries where the employment rates are at high levels, such as Finland, France and Austria, have managed to balance the employment rates for people with disabilities at relatively high levels. In contrast, countries with lower levels of participation in employment, such as Greece and Spain, seem to provide limited opportunity for accessibility to the labour market (Greek National Confederation of Disabled People, European Disability Forum, 2001, p. 14-15).

Evidence shows that in the United Kingdom, the legislation of the Disability Discrimination Act (DDA) which was enacted in 1996, may not have been effective in decreasing the gap that exists between the employment rates of people with disabilities and the non-disabled. The employment rate of the disabled in 1990 was $54.3 \%$ and decreased to $45.9 \%$ in 2001 against that of the non-disabled which increased from $78.3 \%$ to $82.4 \%$ within the same period. As becomes apparent through the research, the battle against discrimination on a legislative basis can achieve significant goals such as accessibility to certain services but legislation alone cannot constitute the most effective means to increasing the rates of employment for the disabled people. Political interventions on issues, such as return to the workplace, occupational rehabilitation or welfare in the workplace can prove to be more effective (Pope D., Bambra C., 2005, p. 1263, 1265). There are about six million people in the UK ( $18 \%$ of the working-age population) reporting some form of restriction on working due to long-term illness or disability. In the UK, the long-term unemployment rate is $38 \%$ for disabled people, compared to $26 \%$ for non-disabled people. Surveys implemented in the UK have shown that most employers in the UK are aware of the legislation on people with disabilities and they have positive intentions to meet their legal obligations. However, few of them activate the state schemes for promoting the employment of the disabled. The personal skills which appear to be crucial for successful performance of the disabled at work are interpersonal social skills and ability to handle information (Stevens, 2002, p. 779 and 792).

Conclusions drawn from another study in the UK show that the National Minimum Wage has benefited disabled people by making low paid jobs better paid. On the other hand, technological progress increases the chances of establishing new workplaces for people with disabilities (Schneider \& Dutton, 2002, p. 283 and 303). 
Findings from other surveys carried out in the USA reveal that there is an apparent association of disability and gender, both being restrictions to employment. It was noticed that the risk of unemployment for women with disabilities was higher than that of men and similarly, a noticeable disparity of participation in employment for women appears between people without disabilities, as women without disabilities were at a higher risk of being unemployed than men without disabilities (Randolph S. D., Andersen M. E., 2004, pp. 411-412). Furthermore, despite all the efforts and progress achieved by the Americans with Disabilities Act (ADA) since it was implemented, a significant number of people with disabilities in the USA remain unemployed due to various obstacles in human relations and other misconceptions about the abilities of the disabled in the workplace (Chima O. Felix, 2005, p. 57).

\section{Methodology}

The data of the primary research are the outcome of a study on "the employment status of people with disabilities who experience any form of discrimination and inequalities", a survey which was conducted within the framework of Community Initiative Programme EQUAL and the project 'Proklisi'. Regarding the methodology of this primary survey, a group of scientists (Magoulios George et al., 2003) designed a questionnaire which was composed of a) personal data of the respondents (16 questions), b) social confrontation (8 questions), and c) employment (9 questions). The survey was conducted on a sample of 1500 Disabled People (DP) throughout the country. The sample was representative, taken on a random selection from the total population of DP (8,500 people), as registered in the records of the Greek Manpower Employment Organization (O.A.E.D.). The survey accepted the definition used by OAED, where disabled people are defined as "people with limited capacities for professional occupation due to physical, intellectual or psychological disease or injury (disability rate $>50 \%$ )". The features of the population refer to both males and females above 18years and include all forms of disability. The questionnaires, which were filled in after personal interviews at each respondent's home, reached a number of 1,386 . The response rate was $92.4 \%$, proportionately distributed to the regions, age and disability category of respondents.

The interviews were taken within the period from July 2003 to September 2003 by 44 interviewers who had attended an appropriate seminar to make them aware of the concept and the objectives of the study and get them qualified for the methodology to be followed concerning the sample and the questionnaire respectively. The interviewers were accompanied by four supervisors who had been well-trained and when all interviews had been completed, the supervisors were asked to go through a sample of $5 \%$ of the questionnaires for a final inspection in which no error was found. 


\section{Sample features}

The study sample consisted of 1386 people with disabilities, living in urban areas of 10 Regions (out of a total of 13) and 14 prefectures (out of a total of 52) in Greece. A large proportion of the sample (89.5\%) was at working age of $18-45$ years. Regarding distribution by gender, $42.2 \%$ of the interviewees were females. Quite a significant number of the questioned (approx.70\%) were single. The sample included people with all forms of disabilities, the most common of which: multiple disability $(12.9 \%)$, emotional and mental disorders $(10.4 \%)$, blindness $(7 \%)$, deafness/hearing problems $(5 \%)$, intellectual retardation $(5.1)$, paraplegia $(4.8 \%)$, thalassemia $(4.8 \%)$ and monoplegia (4.7\%). On the whole, they did not suffer severe disability and were able to respond to the interview by themselves.

Investigating the causes of disability of the people interviewed, it transpired that their impairment was either present at birth $35.9 \%$ or resulted from later injury $13.9 \%$ (traffic accident 6.3\%, work related accident 2.2\%, medical accident $2.2 \%$, other $3.2 \%$ ), from disease $34.1 \%$, from substances use $2.1 \%$, due to personal problems/ stress $5.8 \%$, due to unidentified causes $5.6 \%$ and other causes $1.3 \%$.

The interviewees were asked to report if they belong to any other special socially sensitive group apart from that of the disabled in order to ascertain the likelihood of potential multiple discrimination. From their response, it emerged that 41 people (3\%) are immigrants, 18 people (1.3\%) are repatriated-ethnic Greeks and 45 people $(3.2 \%)$ are drug users either addicted or ex-addicts in therapeutic procedure and alcoholics. $7.5 \%$ of the interviewees (104 people), apart from disability, also belong to other vulnerable groups.

As regards to their educational status, $2.3 \%$ of the interviewees reported no form of education or partial attendance of primary school, $12.8 \%$ have finished Primary School, $16.7 \%$ have completed the nine-year obligatory education, $35.6 \%$ graduated High School or other secondary technical school, 10.1\% post-secondary schools (IEK), 8\% Technological Education Institutes (TEI), 13\% hold University degrees whilst $1.1 \%$ reported Master's degree or $\mathrm{PhD}$. In the total of the people questioned, only $14 \%$ reported having attended a special school for the disabled against $84.8 \%$ who have not.

At the time of the conducted survey, a percentage of 35.9 of the sample were employed whereas $89.2 \%$ stated they were interested in working.

In terms of insurance, $91 \%$ of the interviewees appear to be insured and approximately $8 \%$ are uninsured. The majority of them $(54.3 \%)$ are under Social Security Foundation (IKA) insurance and next in order are those under State insurance $(10.8 \%)$, those who have other kinds of insurance $(8.9 \%)$, those who are on welfare (8.2\%), the ones under self-employed insurance (TEBE) (4.7\%), under Agricultural Insurance (OGA) $(4.5 \%)$, some who have private insurance $(0.6 \%)$ or others who stated other kinds of insurance $(8.9 \%)$. 


\section{Employment of the disabled in Greece: primary research results}

\subsection{Education and employment}

In a question about the importance of education to getting a job, almost $50 \%$ of the total believed that their studies were of great to medium importance to their employment. The percentage of women who reported a positive contribution of their studies to employment was higher than that of men.

\subsection{Factors influencing the decision on employment}

Following an evaluation of the role of certain factors in the decision to get a job, people with disabilities seem to give first priority to the need for survival and next come in declining order their skills, their equal right for participation in employment in the same proportion to social acknowledgement, their inherent inclination and their qualifications (table 1).

Table 1. Factors influencing the decision on employment

\begin{tabular}{lccccccccccccc}
\hline \multicolumn{1}{c}{ Factor } & \multicolumn{2}{c}{$\begin{array}{c}\text { Very } \\
\text { important }\end{array}$} & \multicolumn{2}{c}{$\begin{array}{c}\text { Quite } \\
\text { important }\end{array}$} & \multicolumn{2}{c}{ Of little } & \multicolumn{2}{c}{$\begin{array}{c}\text { Of no } \\
\text { importance }\end{array}$} & \multicolumn{2}{c}{$\begin{array}{c}\text { No } \\
\text { importance }\end{array}$} & \multicolumn{2}{c}{ response } \\
\hline & $\mathrm{N}$ & $\%$ & $\mathrm{~N}$ & $\%$ & $\mathrm{~N}$ & $\%$ & $\mathrm{~N}$ & $\%$ & $\mathrm{~N}$ & $\%$ & $\mathrm{~N}$ & $\%$ \\
\hline Need for survival & 1081 & 78.0 & 200 & 14.4 & 55 & 4,0 & 14 & 1,0 & 36 & 2.6 & 1386 & 100 \\
& 722 & 5.1 & 423 & 30.5 & 145 & 10.5 & 51 & 3.7 & 45 & 3.2 & 1386 & 100 \\
Skills & & & & & & & & & & & & \\
$\begin{array}{l}\text { Equal participation } \\
\text { in employment }\end{array}$ & 764 & 55.1 & 279 & 20.1 & 153 & 11.0 & 122 & 8.8 & 68 & 4.9 & 1386 & 100 \\
$\begin{array}{l}\text { Social } \\
\text { acknowledgement }\end{array}$ & 688 & 49.6 & 351 & 25.3 & 184 & 13.3 & 109 & 7.9 & 54 & 3.9 & 1386 & 100 \\
& & & & & & & & & & & & \\
Inherent inclination & 524 & 37.8 & 373 & 26.9 & 243 & 17.5 & 185 & 13.3 & 61 & 4.4 & 1386 & 100 \\
Qualifications/Studies & 523 & 37.7 & 330 & 23.8 & 252 & 18.2 & 177 & 12.8 & 104 & 7.5 & 1386 & 100 \\
\hline
\end{tabular}

The rate of influence and the importance of each factor do not seem to differentiate by gender significantly, except for the fact that women place greater importance on inherent inclinations, skills and qualifications than men. Analysis based on their educational status, reveals that mainly those who have received primary education and the unemployed attach minor importance to all factors. Additionally, the form of disability is an influence on the evaluation of these same factors, since those with vision problems, mental retardation or mental diseases and multiple disabilities express low evaluation for all factors including inherent inclination and qualifications. 


\subsection{Integration in the labour market}

Among the disabled who were interviewed, 35.9\% are currently employed. Taking into account that $90 \%$ of the disabled interviewees reported themselves keen to work, then the rate of unemployment for people with disabilities is as high as $71.8 \%$. In the total Greek population above 15 years old, the proportion of the unemployed is at $9.34 \%$ of the labour force (men at $6.02 \%$ and women at $14.32 \%$ ) (2003 last quarter, NSSG).

The proportion of unemployed is higher for women, primary school and junior high school graduates, the single and divorced, those with mental diseases, repatriated ethnic Greeks and alcohol addicts than the total average. It is obvious that the above categories suffer multiple discriminations in pursuit of integration in the labour market. Unemployment proves to be the top problem for the disabled and although it is a matter of concern for all of them, it is most likely to bring some more tension to the categories mentioned above.

Among the interviewees who are not currently employed, 67.1\% stated that they have worked in the past.

Regarding the duration of employment, collected data show that among those who have worked in the past, $29 \%$ worked for one year, $24.3 \%$ worked for $1-3$ years, $9.8 \%$ worked for 3-5 years, $17.5 \%$ worked for 5-10 years and 14\% worked for more than ten years.

In contrast, $19.5 \%$ of the unemployed have been out of work for a period up to one year, $20.6 \%$ have been unemployed for $1-3$ years, $15.65 \%$ for $3-5$ years and $37.8 \%$ for more than 5 years. $80 \%$ of the disabled are long-term unemployed.

Thus, along with the high unemployment rate there seem to co-exist equally high rates of long-term unemployment while at the same time the duration of employment for those who have worked or those who are currently employed is unclear. These findings reflect the problem of exclusion of the disabled from the labour market and reinforce the demand for action by the state to tackle the problem.

Regarding the infrastructure enabling access to work for the disabled, $16.2 \%$ of the questioned are reported to be very satisfied with it, $27.8 \%$ expressed their moderate satisfaction and $32.2 \%$ are not satisfied at all.

\subsection{Type and sector of employment and coherence to the field of study}

\subsubsection{Type and sector of employment}

Among the people who are currently employed, $70.6 \%$ are in full-time employment whereas $18.3 \%$ of them have part time jobs and $10.7 \%$ are self-employed. A large proportion of the sample (72\%) are employed in the private sector and almost $27 \%$ work in the public sector. 


\subsubsection{Duration of employment}

A proportion of $34 \%$ of those who are currently employed have been in employment for about a year, $27.56 \%$ have been working for one to three years, $15.5 \%$ for three to five years, $6.63 \%$ for five to ten years and $7.24 \%$ have been employed for more than ten years (Table 2).

Table 2. Duration of employment

\begin{tabular}{lcc}
\hline period of employment & $\mathrm{N}$ & $\%$ \\
\hline$\leq 1$ year & 169 & 34.0 \\
1-3 years & 137 & 27.6 \\
3-5 years & 77 & 15.5 \\
5-10 years & 33 & 6.6 \\
More than 10 years & 36 & 7.2 \\
No response & 45 & 9.1 \\
Total & 497 & 100 \\
\hline
\end{tabular}

\subsubsection{Coherence between studies and employment}

The interviewees who are currently employed were asked whether their field of studies is coupled or related in any way to their current occupation. $26.04 \%$ of them reported relevance between studies and occupation whereas $51.50 \%$ reported no relevance and $16.71 \%$ said that sometimes they had relevant occupations.

\subsubsection{Characteristics of disabled employees}

Considering all the characteristics of employed people with disabilities, it emerges that the majority of them - seven in ten - are full-time employed and the rest of them are in part-time jobs or self-employed. Gender, education and family status do not seem to influence the type of employment in contrast to the form of disability, which is connected with the higher rate of full-time employment for people with problems of vision or deafness. Among women, immigrants and repatriates, the percentage of those who work in the private sector is much higher than in the public sector. By contrast, the percentages of people with hearing problems, deafness and multiple disabilities who are employed in the public sector are at a higher rate than the respective total average. Only $1 / 4$ of the employed disabled stated direct relevance between studies and occupation compared to half of them who stated no relevance or some relevance at certain occupations. 


\subsection{Attitudes at working environment}

The interviewees who are currently employed or have worked in the past were asked to evaluate the behaviour of their employer, the executive managers, their colleagues, as well as the working environment and the attitude of customers while at work (Table 3).

Table 3. Evaluation on attitudes while at work

\begin{tabular}{lcccccccccc}
\hline $\begin{array}{l}\text { Evaluation } \\
\text { comments } \\
\text { on: }\end{array}$ & \multicolumn{1}{c}{ Satisfactory } & \multicolumn{2}{c}{ Average } & \multicolumn{2}{c}{ Not good } & No response & \multicolumn{2}{c}{ Total } \\
\cline { 2 - 10 } & $\mathrm{N}$ & $\%$ & $\mathrm{~N}$ & $\%$ & $\mathrm{~N}$ & $\%$ & $\mathrm{~N}$ & $\%$ & $\mathrm{~N}$ & $\%$ \\
\hline $\begin{array}{l}\text { Colleagues' } \\
\text { attitude }\end{array}$ & 641 & 62.3 & 245 & 23.8 & 60 & 5.8 & 83 & 8.1 & 1029 & 100 \\
$\begin{array}{l}\text { Employer's } \\
\text { attitude }\end{array}$ & 560 & 54.4 & 298 & 29.0 & 110 & 10.7 & 61 & 5.9 & 1029 & 100 \\
$\begin{array}{l}\text { Customers' } \\
\text { attitude }\end{array}$ & 557 & 54.1 & 298 & 29.0 & 38 & 3.7 & 136 & 13.2 & 1029 & 100 \\
$\begin{array}{l}\text { Managers' } \\
\text { attitude }\end{array}$ & 540 & 52.5 & 293 & 28.5 & 76 & 7.4 & 120 & 11.6 & 1029 & 100 \\
$\begin{array}{l}\text { Working } \\
\text { environment }\end{array}$ & 537 & 52.2 & 334 & 32.5 & 99 & 9.6 & 59 & 5.7 & 1029 & 100 \\
\hline
\end{tabular}

\subsection{Parameters in job-seeking}

The interviewees were asked to define the importance of the role of certain parameters involved in job-seeking based on their own experience. Below are presented the data which emerged from the analysis of their answers (Table 4).

Investigating the role of certain parameters in job seeking, it becomes clear that the most positive role is played by skills and qualifications, cited by $3 / 4$ of the questioned, next in priority come work experience, qualifications and studies, exploitation of subsidiary projects, cited by $3 / 5$ of the questioned, and last comes the employer's attitude towards DP problems, selected by half of the respondents. As most negative parameters were selected age, the employer's attitude towards DP problems, accessibility to workplace, gender, family status and qualifications, work experience, former experience of the employer on DP employment, the exploitation of subsidiary projects and skills and qualifications for the position in order of reference. Finally, under the selection of neutral most participants placed the parameter of gender followed by family status, accessibility of the workplace, former experience of the employer on DP employment, age, the employer's attitude towards DP problems, qualifications, work experience, the exploitation of subsidiary projects and skills and qualifications of the candidate. 
Table 4. The role of parameters in job-seeking

\begin{tabular}{|c|c|c|c|c|c|c|c|c|c|c|}
\hline \multirow[t]{2}{*}{ Parameter } & \multicolumn{2}{|c|}{ Very Positive } & \multicolumn{2}{|c|}{ Neutral } & \multicolumn{2}{|c|}{ Negative } & \multicolumn{2}{|c|}{ No response } & \multicolumn{2}{|c|}{ Total } \\
\hline & $\mathrm{N}$ & $\%$ & $\mathrm{~N}$ & $\%$ & $\mathrm{~N}$ & $\%$ & $\mathrm{~N}$ & $\%$ & $\mathrm{~N}$ & $\%$ \\
\hline $\begin{array}{l}\text { Skills and } \\
\text { qualifications } \\
\text { for the position }\end{array}$ & 1011 & 72.9 & 219 & 15.8 & 88 & 6.4 & 68 & 4.9 & 1386 & 100 \\
\hline Work experience & 862 & 62.2 & 271 & 19.6 & 111 & 8.0 & 142 & 10.2 & 1386 & 100 \\
\hline $\begin{array}{l}\text { Qualifications/ } \\
\text { Higher Education }\end{array}$ & 838 & 60.5 & 321 & 23.2 & 124 & 8.9 & 103 & 7.4 & 1386 & 100 \\
\hline $\begin{array}{l}\text { Exploitation of } \\
\text { subsidiary projects }\end{array}$ & 820 & 59.2 & 270 & 19.5 & 89 & 6.4 & 207 & 14.9 & 1386 & 100 \\
\hline $\begin{array}{l}\text { Employers' attitude } \\
\text { to DP problems }\end{array}$ & 693 & 50.0 & 368 & 26.5 & 187 & 13.5 & 138 & 10.0 & 1386 & 100 \\
\hline Age & 675 & 48.7 & 439 & 31.7 & 205 & 14.8 & 67 & 4.8 & 1386 & 100 \\
\hline Family Status & 566 & 40.8 & 628 & 45.3 & 123 & 8.9 & 69 & 5.0 & 1386 & 100 \\
\hline $\begin{array}{l}\text { Former experience } \\
\text { of the employer on } \\
\text { DP employment }\end{array}$ & 565 & 40.8 & 465 & 33.5 & 91 & 6.6 & 265 & 19.1 & 1386 & 100 \\
\hline $\begin{array}{l}\text { Accessibility } \\
\text { to workplace }\end{array}$ & 517 & 37.3 & 481 & 34.7 & 186 & 13.4 & 202 & 14.6 & 1386 & 100 \\
\hline Gender & 482 & 34.8 & 638 & 46.0 & 129 & 9.3 & 137 & 9.9 & 1386 & 100 \\
\hline
\end{tabular}

\subsection{Means utilized in search of employment}

Responding to a relevant question, the participants reported the means they may have used in their attempt to find employment in the following priority shown on table 5.

Table 5. Means utilized in job seeking

\begin{tabular}{|c|c|c|c|c|c|c|c|c|c|c|}
\hline \multirow[t]{2}{*}{ Means } & \multicolumn{2}{|c|}{$1^{\mathrm{st}}$ choice } & \multicolumn{2}{|c|}{$2^{\text {nd }}$ choice } & \multicolumn{2}{|c|}{ 3nd choice } & \multicolumn{2}{|c|}{ No response } & \multicolumn{2}{|c|}{ Total } \\
\hline & $\mathrm{N}$ & $\%$ & $\mathrm{~N}$ & $\%$ & $\mathrm{~N}$ & $\%$ & $\mathrm{~N}$ & $\%$ & $\mathrm{~N}$ & $\%$ \\
\hline $\begin{array}{l}\text { Acquaintance with } \\
\text { the employer }\end{array}$ & 362 & 26.1 & 180 & 13.0 & 120 & 8.7 & 724 & 52.2 & 1386 & 100 \\
\hline $\begin{array}{l}\text { OAED subsidiary } \\
\text { schemes }\end{array}$ & 241 & 17.4 & 172 & 12.4 & 129 & 9.3 & 844 & 60.9 & 1386 & 100 \\
\hline Job advertisements & 199 & 14.4 & 198 & 14.3 & 116 & 8.4 & 873 & 62.9 & 1386 & 100 \\
\hline $\begin{array}{l}\text { Personal efforts } \\
\text { besides } \\
\text { acquaintances }\end{array}$ & 261 & 18.8 & 262 & 18.9 & 175 & 12.7 & 688 & 49.6 & 1386 & 100 \\
\hline $\begin{array}{l}\text { Employment } \\
\text { suggested by OAED }\end{array}$ & 111 & 8.0 & 146 & 10.5 & 117 & 8.5 & 1012 & 73.0 & 1386 & 100 \\
\hline Broader network & 112 & 8.1 & 151 & 10.9 & 127 & 9.1 & 996 & 71.9 & 1386 & 100 \\
\hline $\begin{array}{l}\text { Schemes promoting } \\
\text { employment }\end{array}$ & 51 & 3.7 & 65 & 4.7 & 74 & 5.3 & 1196 & 86.3 & 1386 & 100 \\
\hline
\end{tabular}


From the analysis of data on the means the disabled interviewees have used in the process of job-seeking, it appears that most frequently job-seekers used personal or family acquaintance with the employer and then chose to exploit other means such as subsidiary projects of OAED, job advertisements, seeking efforts of their own besides acquaintances, employers suggested by OAED and their broader network. As a last choice they used schemes promoting employment.

\section{Conclusions}

People with disabilities at an International level often face disproportionate levels of poverty and unemployment while there seems to be a direct association between disability and poverty. Disabled people are at great risk of being unemployed or inactive and a high proportion of employed people belong to poorly-paid groups. This study showed that the need for survival seems to be the most important factor influencing the decision of disabled people on employment.

In the EU, the participation of people with disabilities in the labour force is limited as they not only face restrictions in finding a job but also in retaining one. Despite legislation, government schemes and programs, disabled people are disproportionally represented in unemployment figures - with proportionally more wanting to work than their non-disabled peers. The state of employment of people with disabilities in Greece is particularly discouraging, compared to the EU average, reflecting their poor integration into the labour market.

The data were collected in 2003 and until now no other similar research has been implemented at national or European level. Recently in Greece, due to the economic crisis, there have been significant changes in the labor market, with the unemployment rate now at approximately $15 \%$. As the United Nations expert Lumina said "The implementation of the second package of austerity measures and structural reforms, including a wholesale privatization of state enterprises and assets are likely to have serious implications for basic social services and, therefore, the enjoyment of human rights by the Greek people, particularly the most vulnerable populations, such as poor, the elderly, the unemployed and people with disabilities" (UN Human Rights, Lumina Cephas, 2011).

Greek research in the state of employment of people with disabilities is very limited and only recently, within the framework of European programs, such as Equal, has there been a growing interest in examining the disabled employees' attitudes and experiences in the workplace environment as well as the employers attitudes to employees with disabilities. This study aims to examine, at the micro level, the state of employment of people with disabilities.

From the evaluation of the parameters influencing decision-making on employment, it becomes clear that the disabled place great importance on their survival needs, and following in a list of priorities are their skills, equal participation to employment and 
social recognition, inherent inclinations and personal qualifications. The importance of the parameters does not seem to differentiate by gender except for these related to inherent inclinations, skills and qualifications on which women apparently place more emphasis than men.

This study showed that the vast majority of the disabled claim to be most interested in working but in spite of all interest and eagerness to work, most of them are unemployed. The proportion of unemployed women, poorly educated, unmarried and divorced, mentally sick, repatriated and addicts is higher than the total average. Apparently, the above mentioned categories suffer multiple discriminations in their pursuit of integration into the labour market. The implication seem to be that a high rate of unemployment is accompanied by a simultaneous high rate of long-term unemployment as well as a wide variation in the duration of employment for those who have worked. These findings reflect the exclusion of the disabled from the labour market and indicate that the government should take measures and initiatives to tackle the problem. Many other research findings support the conclusion that women with disabilities face multiple difficulties in integrating into the labour market (Randolph S. D., Andersen M. E., 2004, pp. 411-412 \& European Commission, DG Employment, Social Affairs and Equal Opportunities, 2007, p.39).

The findings of this research indicate that the majority of disabled employees seven in ten - are in full-time employment and the rest of them are either in part-time jobs or self-employed. The majority of the respondents reported that their studies did not play an important role in finding a job, and that the study curriculum does not seem to meet the needs of the labour market, which is a serious drawback of the overall educational system. This finding is contradicted by the study carried out by the DG Employment, Social Affairs and Equal Opportunities, according to which the level of education seems to be a significant factor in increasing both participation and employment rates of those with long-standing health problems or disability (European Commission, 2007, p.15).

Through the evaluation of attitudes at work it emerges that the behaviours of colleagues, employers, customers and managers are quite satisfactory for most employed people with disabilities. On the other hand, through the evaluation of their own performance at work, the disabled people seem to consider themselves equally capable or in some cases more efficient than other non-disabled colleagues.

The most positive influence of certain parameters involved in job-seeking seems to be identified by the respondents as skills and their personal qualities. Similar studies in the UK have showed that personal skills, particularly interpersonal social skills, appear to be crucial for successful performance of the disabled at work (Stevens, 2002, p. 779 and 792). 
Furthermore, the study showed that the means which is most frequently used in the process of job-seeking is personal or family acquaintance with the employer, followed by OAED subsidiary schemes, job advertisements, personal efforts other than via acquaintances, employers suggested by OAED, broader network and participation in other programmes promoting employment.

Considering all the above, employment of people with disabilities is apparently a most significant problem in terms of high rates of unemployment and longterm unemployment as well as wide variation in terms of duration and stability in employment for the already-employed disabled people. Apart from legislation and government schemes promoting the employment of disabled people in public and private workplaces, other equally important elements to be dealt with are: the necessary education and vocational training in order to provide qualifications to the disabled so that they can meet the needs of the labour market, conscious and systematic planning of new workplaces available for the disabled, particularly in the social economy, provided by those acting in local, social, and self-administrated development. In addition, it is crucial to raise awareness and consideration of the employment of the disabled among employment organizations, employers and administrative executives, reinforcing at the same time their motivation to employ people with disabilities and thereby ensuring their long-term and stable employment.

\section{References}

Chima O. Felix, 2005, "Persons with Disabilities and Employment: Implications for Social Work and Rehabilitation Roles and Advocacy", Journal of the Social Work in Disability \& Rehabilitation, Vol. 4(3), p. 57.

Cohen D.F.B., Zeitzer I.R., "How Governments Can Use Technology to Promote Employment of People with Disabilities", Lecture Notes in Computer Science, 3118, 2004, p. 45).

Council Directive 2000/78/EC of 27 November 2000, "establishing a general framework for equal treatment in employment and occupation", Official Journal of EC (L 303, 02.12.2000).

European Commission: Commission Communication of 30 October 2003 - Equal opportunities for people with disabilities: a European Action Plan [COM (2003) 650] and Commission Communication of 28 November 2005 - Situation of disabled people in the enlarged European Union: The European Action Plan 2006-2007 [COM (2005) 604].

European Commission, DG Employment, Social Affairs and Equal Opportunities, 2007, "Men and women with disabilities in the EU: Statistical analysis of the LFS ad hoc module and the EUSilc", p. 15, 39.

European Commission, 2004, "Monitor social situation in the European Union 2004 (Observatory)", p. 34 .

Eurostat, 2003, “Employment of disabled people in Europe in 2002”, pp. 1-3. Eurostat, Data 2003, "European Social Statistics Labour Market Policy Expenditure and Participants”, p. 12, 14.

Greek National Confederation of Disabled People, European Disability Forum, 2001, "Disability and Social Exclusion in the European Union Time for change, tools for change”, p. 14-15. 
ILO, 2007, "ILO calls for new efforts to support people with disabilities in the world work".

Magoulios, G. et al., 2003, "Primary Research on the employment status of people with disabilities experiencing simple or multiple discriminations", Equal project 'Proklisi', July-September 2003, Greece - partner representatives: European Development S.A. Magoulios N. George, coordinator of the research project and in charge of the survey group, Trichopoulou Anna, Papadopoulou Eleni, National Confederation for People with Disabilities (ESAEA), Research Centre for Gender Equality (KETHI), Greek Manpower Employment Organisation (OAED), Organisation Against Drugs (OKANA), Panhellenic Association for the Blind (PST), International Organisation for Migration (IOM), Hellenic Association of Social Workers (SKLE) and Hellenic Federation for the Deaf (OMKE).

National Statistical Service of Greece (NSSG), 2003 and 2001, Population Census.

National Statistical Service of Greece (2003), Health and Inequality, Athens.

Pope D., Bambra C., 2005, "Has the Disability Discrimination Act closed the employment gap?", Disability and Rehabilitation 27 (20), p. 1263, 1265.

Priestley Mark, "Why We Need to Work Together in the European Year of Disabled People", Disability \& Society, Vol. 17, No. 7, 2002, pp. 846-848.

Randolph S. D., Andresen M. E., 2004, "Disability, gender, and unemployment relationships in the United States from the behavioural risk factor surveillance system", Disability \& Society, Vol. 19, No. 4, pp. 411-412.

Roulstone Alan, "Disabling Pasts, Enabling Futures? How Does the Changing Nature of Capitalism Impact on the Disabled and Jobseeker?", Disability \& Society, Vol. 17, No 6, 2002, p. 636.

Russell Marta, "What Disability Civil Rights Cannot Do: employment and political economy", Disability \& Society, Vol. 17, No. 2, 2002, pp. 130-131.

Schneider Justine \& Dutton Jillian, "Attitudes Towards Disabled Staff and the Effect of the National Minimum Wage: a Delphi survey of employers and disability employment advisors", Disability \& Society, Vol. 17, No 3, 2002, p. 283 \& 303.

Stevens Geoff Ruggeri, "Employers' Perceptions and Practice in the Employability of Disabled People: a survey of companies in south east UK", Disability \& Society, Vol. 17, No. 7, 2002, p. 779 and 792.

United Nations (1993), "Standard Rules on the Equalization of Opportunities for People with Disabilities", New York, United Nations.

UN Human Rights, 2011, Lumina Cephas, Greek crisis: "Keep in mind the basic human rights of people" - United Nations experts on the rights and foreign debt. 